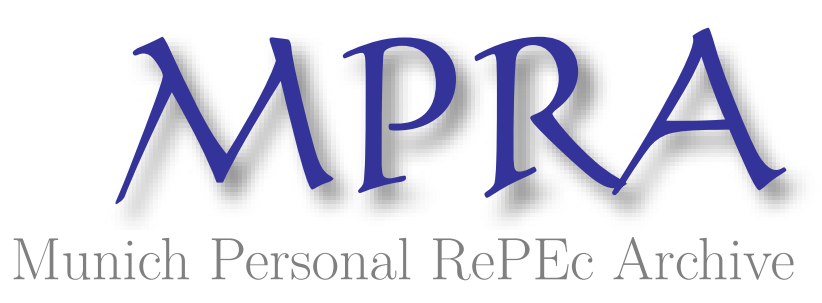

\title{
Civic Culture and Economic Transition in Russia
}

Polterovich, Victor

New Economic School

2000

Online at https://mpra.ub.uni-muenchen.de/20068/

MPRA Paper No. 20068, posted 18 Jan 2010 11:00 UTC 


\title{
Civic Culture and Economic Transition in Russia ${ }^{1}$
}

\author{
Victor Polterovich \\ CEMI RAS and NES
}

Moscow

\section{CONTENT}

1. Introduction

2. Cultural factors in explanations of transition phenomena

3. An Individual and the Socialist State: a dual nature of paternalism

4. Passivity

5.Attitude towards official rules, legal norms and law enforcement institutions: habitual deviationism

6. Workers' collectivism and "social responsibility" of managers

7. Attitude towards foreigners

8. Attitude towards market institutions

9. Attitude towards democratic institutions and liberal values

10. Manipulability

11. The culture of governance

12. Consensus governance and interim institutions

13. Civic culture and transformational recession

14. Conclusions

\section{Introduction}

Almond and Verba (1963, p.5) regard the civic culture as including "the ways in which political elites make decisions, their norms and attitudes, as well as the norms and attitudes of the ordinary citizen, his relation to government and to his fellow citizens". They consider "social trust and cooperativeness as a component of the civic culture" (p. 490). This definition of the civic culture seems to be even broader than the notion of political culture (Lijpart, 1989). However, throughout most part of the book cited, Almond and Verba define the civic culture as an ideal "rationality-activist model" of a democratic society in which individuals are active, well informed and positively oriented to the political structures and processes and in which "the subject and parochial orientations are congruent with the participant

\footnotetext{
${ }^{1}$ A revised version of the paper that was presented at the 15-th Annual Congress of the European Economic Association (Bozen- Bolzano, 30-th August - 2-nd September 2000). I would like to thank
} 
political orientations." (pp.31-32) ${ }^{2}$. The civic culture is "a culture of consensus and diversity", a culture that permits change but moderates it" (p. 8).

In this paper the term "civic culture" is understood in a broad sense: as a system of individual attitudes towards political, administrative, and economic structures prevailing in a society. For examples, attitudes towards liberal values, democracy, observance of law, towards government and competition, the rich or immigrants, towards superiors and subordinates, towards bureaucracy and police are all elements of the civic culture.

About ten years ago, more than twenty-five socialist countries including the former Soviet republics started their transition paths to the market economy. Despite country differences, reformers have implemented very similar strategies as ten statements of «Washington consensus» described it. Liberalization, privatization, and deregulation were the main measures to conduct.

The recipe for the reforms was based on the implicit assumption that the cultural particularities of a country (and other initial conditions) are much less significant than the general framework of the market mechanism. It was presumed that the mechanism would be quickly adopted and the reformed economies would start to grow. Instead, the reforms resulted in deep transformational recession ${ }^{3}$ that could be explained by neither shortage of labor or capital ${ }^{4}$, nor by lack of demand or inflation costs. It is a widely accepted view now that the most important causes of the recession were the weakness of the new market institutions and the low quality of governance. The invisible hand of the market is suppressed by the grabbing hand of the state. The role of government was underestimated: it was the government who had to enforce new market-oriented norms of behavior (Stiglitz, 1997).

These conclusions need deeper discussions and explanations. First, one should explain why the quality of governance was low and why the state turned out to be a grabbing hand. Second, one should ask whether stronger enforcement was possible and whether it would have resulted in better outcomes. The culture of governance is a part of the civic culture prevailing. Given a civic culture, could we expect quick

\footnotetext{
Judith Shapiro for useful comments and invaluable editorial help. All mistakes are my own.

${ }^{3}$ After ten years of the reform only three among 26 transition economies -Poland, Slovakia, and Slovenia- had reached their pre-reform GDP levels [Economic Survey of Europe , 2002, p. 230]. ${ }^{4}$ In Russia surveys registered an excess of labor and underutilization of capacities during last ten years.
} 
improvements in governance? The recommendation to strengthen law enforcement assumes implicitly that a strategy of the reforms is fixed. However it is changing in reality under the pressure of circumstances, and it seems to be reasonable to adjust the plan of reforms in advance. To put the same question by another way, let us imagine an outside adviser who recognizes that the quality of a government in a country is too poor to conduct a successful reform. What would be a wise advice - change ministers and improve routines, or develop a new strategy for the reform?

The cultural aspects of economic development as well as interrelations between the civic culture and democracy have been studied in the vast literature devoted to modernization of underdeveloped societies (a number of references may be found in Almond and Verba (1989), Casson (1993), Fang (2001)). However, the cultural problems of most former socialist countries are quite different. In this case we have well educated and highly industrialized societies where moral, social, and economic norms of behavior were formed under the strong pressure of communist ideology and the totalitarian state. Much research touches upon the influence of some particularities of the "socialist cultural legacy" on the economic transition. But there are few investigations especially devoted to this problem. Among notable exceptions are Kornai, 1985; Linz , 1998; Shleifer, 1997, Hillman (1999), Hillman and Ursprung (2000). An article by Janos Kornai " Efficiency and principles of socialists ethics" and a chapter "Degrees of paternalism" in his "Economics of Shortage" were written long before the beginning of the large-scale reforms, but nevertheless contain important observations directly related to the transition process (Kornai, $1985 \mathrm{a}, \mathrm{b}$ ). They are the starting points of our paper.

In this paper we try to describe the main feature of Russian civic culture that could influence the outcome of the reform, initiated in 1992, and discuss channels through which the influence was realized. We begin with consideration of paternalism and what we call "habitual deviationism", ordinary and routine deviation from official rules and laws. Both features were inherited from the Soviet period ${ }^{5}$. Paternalism and habitual deviationism determine a system of people's attitudes towards the state, the

\footnotetext{
${ }^{\mathbf{5}}$ Our goal is an analysis of influence of the civic culture on the reform's outcome in Russia. Therefore we discuss the cultural norms as they were formed under the Soviet power and during the reforms, and do not consider deeper cultural roots connected to the pre-Soviet period.
} 
law, the property, and the liberal values. It will be demonstrated that this system entails an adversarial (using a term of Stiglitz) style of governance and the opportunism and corruptibility of the ruling elite. It is argued that "shock therapy" may be destructive under this cultural environment and strong initial distortions since fast liberalization and privatization release a huge volume of rent and strengthen incentives for rent seeking activity. It is further argued that a good reform strategy should take civic culture into account and not put forward overly ambitious tasks. One has to built a sequence of interim institutions which would be more congruent to the initial cultural and institutional environment, facilitate the adaptation of the people, and stimulate modernization of cultural norms to reach an effective market system with time.

\section{Cultural factors in explanations of transition phenomena}

Cultural factors are explicitly or, more often, implicitly embedded in explanations of many transition phenomena. In particularly, this is related to models with multiple equilibria that are widely used to study a jump in corruption, tax evasion, or arrears soon after the start of the market reforms. The phenomena are explained as stable inefficient equilibria, "lock-ins" or "institutional traps" (see North , 1997; Polterovich, 2000 for a discussion and references). To see an example, let us consider an extremely simplified model of the formation of a corruption trap (Polterovich, 1998).

The model includes a representative official who compares expected gain and loss for two behavior norms: the honest and bribe- taking behavior. The solution depends on the relation of the official wage rate to the bribe level (both presumed to be fixed), and on the probability and disutility of being caught. The probability of being caught is a function of the scale of corruption: the more people are involved in bribe-taking activity the less probable for a concrete bribe -taker to be detected and punished. This is an example of the "coordination mechanism" that gives rise to multiplicity of equilibria.

In the context of this model one can suggest the following explanation of the jump in the corruption level at the start of market reforms. Due to economic liberalization a huge volume of rent, which was expropriated by the state before, becomes available 
for private agents ${ }^{6}$. The gain from rent seeking activity increases drastically, and also the bribe level. The regular wage rate of officials is rigid. Therefore many of those, who previously observed the law, find it preferable to change their behavior. Due to coordination effects, the expected loss of bribe- taking diminishes, and the inferior equilibrium is consolidated. With time, the transition rent may disappear and the bribe level decreases but the corruption norm continues to prevail; this is a hysteresis effect.

There are three points where cultural factors are embedded in this explanation. First, the disutility of being caught depends not only on the strength of punishment but also on peoples' attitudes to bribe-taking behavior. Second, the probability of being caught depends not only on the quality of law enforcement bodies but also on the readiness of other people to cooperate with these bodies to reveal corruption cases.

In fact, there is little hope of defeating corruption without this cooperation. And third, the quality of law enforcement bodies depends on the culture of the ruling elite.

This example shows clearly that explanations of the reform phenomena are at least incomplete if one does not take into account how cultural factors, prevailing in a society, interact with formal institutional changes.

\section{An Individual and the Socialist State: the dual nature of paternalism}

Paternalism is a system of relations between a principal and agents under which the principal takes care about agents but without allowing them any freedom and responsibility. This way of governing produces a special system of attitudes that will be also called paternalism.

Paternalism is a standard characterization of the interrelations between an individual and the socialist state. In addition to the usual state obligations, the socialist state guaranteed a job, a dwelling, free of charge health care and education, and a stable pension for every citizen on reaching retirement age. It also promised "a steady growth of the public wealth". In exchange, the state declared the priority of common interests over private ones, and required that the state itself would be recognized as the sole agent who knew and expressed common interests. Every person had to serve the State, act, write, and speak in accordance to the State ideology. This was the other

\footnotetext{
${ }^{6}$ In Russia, the domestic prices of oil, fuel, non-ferrous metals were several times lower than the world prices in 1992. An access to the foreign trade was extremely attractive.
} 
side of the implicit contract. The right of total control was based on the obligations to provide protection and welfare.

The Soviet economic mechanism was designed in such a way that the state could fulfill a part of its obligations. A policy of price stability and full employment was maintained. Managers had no incentives to fire workers, and labor hoarding prevailed. Bankruptcies were impossible. Every firm, when in trouble, could count on the help of the state. This was possible due to large-scale redistribution of GDP through the state budget: the state extracted the profit of successful firms to support unprofitable ones. $^{7}$ In fact, a similar policy was implemented with respect to the individual: wage differentiation was low which meant that more productive workers were donors to less productive ones. The bulk of investment, that is all new building of large and medium size enterprises, was carried out by the state. Under conditions of all-embracing shortage, goods produced were almost surely sold. Marketing problems were, in fact, unknown. Financial markets did not exist. Goods' speculation was illegal. Since the state was the sole owner of capital and took a major part of the risk it also pretended to deserve most of the returns from all sorts of activities. Individual incentives for innovations were weak. All civic organizations including professional societies and clubs of interests were under strict state control.

A typical Soviet individual lived all his/her life in the same town or village, very seldom changed his/her job, and voted for one ruling party. Many kinds of activities were forbidden or restricted.

This system formed paternalistic expectations that involved a number of behavioral consequences. Lack of options, the numerous restrictions gave rise to the passivity of law-abiding citizens, and their unwillingness to try to influence a situation.

The implicit contract between citizens and the state was formulated and interpreted by the state which, if necessary, did not hesitate to break it directly. Main dogmas of the communist ideology contradicted the real facts. The state was not able to fulfill many of its obligations and promises, suppressed free exchange of information and any political and intellectual opposition. The numerous restrictions created broad possibilities for rent seeking. The party and state bureaucracy wallowed in corruption.

\footnotetext{
${ }^{7}$ Since the prices were rigid and highly distorted the permanently negative profit did not indicate that the enterprise had to be shut down.
} 
Unfulfilled paternalistic expectations resulted in deep disappointment in the state and rule of law institutions, and lack of government credibility.

Most people were compelled to break the rules and laws in order to survive, they were in a confrontation with the state, and therefore felt themselves unprotected. A dual attitude towards the state institutions was formed: they were the main sources of wealth and troubles. On one hand, expectations of the numerous state services and, on the other hand, a permanent conflict with and distrust of the state institutions - this is the essence of the dual nature of paternalism as a culture.

Paternalistic attitudes involve longing for a charismatic, strong, wise, and benevolent leader. The first President of Russia, Boris Eltsin, was such a leader in 1991-1992 when the transition started. The reform was an attempt to reconsider the paternalistic contract and work out a new one: the state weakened control and people accepted lower level of social protection. However, this new contract was inside of the system of paternalistic relations: it was the state that carried the reform and promised a quick (after two or three years) rise of living standards.

The state did not fulfill its promises. The people lost their savings during the month following price liberalization when prices jumped as much as to 3.5 times and real wage rate dropped drastically. Fast inflation and deep recession began, government and inter-enterprise arrears crises broke out, corruption and criminal activities flourished. After 7 years the fall in GDP consisted of $40 \%$, and industrial production halved. Social expenditure fell even faster than GDP. The deep political crisis of 1993 and the financial catastrophe of 1998 revealed the ineffectiveness of the new political and market mechanisms.

The population was deeply disappointed. In July 1991 about 30\% of respondents "completely shared Yeltsin's views and stands". The number changed to $11 \%$ in March 1992 already. It was 7\% in November 1993, and merely 3\% in January 2000 (Nikitina, 2000). Table 1 below contains information about attitudes of Russian population towards economic and political state of affairs in November 1997, when inflation was suppressed and economic growth had seemed to begin, and in November 1998 after the financial crisis of August 1998.

The data demonstrate that the majority were deeply disappointed by the reform. The difference between columns reveals that the respondents reacted to the changing situation. In November 1998 the situation was definitely worse as a result of the 
financial crisis, and improved afterwards. Even in 2002,about $40 \%$ of respondents considered financial positions of their families as bad or very bad.

\section{Table 1. Attitudes of Russian population towards economic and political situation (percentage of respondents agreed or rather agreed in a statement)}

\begin{tabular}{|c|c|c|}
\hline Statement & $\begin{array}{l}1997, \\
\text { Nov. }\end{array}$ & $\begin{array}{l}1998, \\
\text { Nov. }\end{array}$ \\
\hline $\begin{array}{l}\text { I experience tension and irritation or fear } \\
\text { and anguish }\end{array}$ & 49 & 56 \\
\hline $\begin{array}{l}\text { I am not satisfied with my life, mostly or } \\
\text { absolutely }\end{array}$ & 45 & 65 \\
\hline $\begin{array}{l}\text { Financial position of my family is bad or } \\
\text { very bad }\end{array}$ & 50 & 65 \\
\hline $\begin{array}{l}\text { Economic situation in Russia is bad or } \\
\text { very bad }\end{array}$ & 69 & 90 \\
\hline $\begin{array}{l}\text { It is impossible to endure our disastrous } \\
\text { situation }\end{array}$ & 38 & 51 \\
\hline $\begin{array}{l}\text { The political situation in Russia is tense } \\
\text { or even critical and explosive }\end{array}$ & 80 & 91 \\
\hline Economic reforms have to be continued & 34 & 27 \\
\hline $\begin{array}{l}\text { How would you grade our President } \\
\text { Yeltsin (Putin) in } 1 \text { to } 10 \text { scale? }\end{array}$ & 3.1 & 1.8 \\
\hline
\end{tabular}

Source: Surveys' Findings (1999, p.61), (2002 p. 65),.

In a 1997 survey, Haarland and Nissen (1999, p.15) found that the proportion of respondents dissatisfied by the course of reforms is equal to $64 \%$ for Poland, $78 \%$ for Czech Republic, 84\% for Hungary, and 89\% for Russia. In 1999 the figures changed up to $78 \%, 87 \%, 76 \%$, and $97 \%$. In all this countries, the people wanted to strengthen the bureaucratic power. About $60 \%$ of the Poland, Czech, and Hungary respondents of the 1997 survey were agreed that "Strong governance is more important now than democracy”. In Russia it was 76\% ( Haarland and Nissen 1999, p.17)

It is well known that government credibility is an important prerequisite of the success of any economic reform ( Bruno, 1993, p. 265). The credibility influences expectations that have a tendency to self-fulfillment. This was particularly true for Russia where the people were strongly oriented toward the state. An evidence of this was a sharp drop of President's credibility described above. 
Paternalistic expectations entail the lack of credibility of the market reform policy and even resistance to it if the government does not make special efforts to compensate losses and to support public and social protection services.

Below we discuss some other consequences of the paternalism and some other elements of the Russian civic culture in greater detail.

\section{Passivity}

I believe that, by formal level of participation, Soviet people would have ranked ahead of developed countries. Almost all Soviet worker were members of trade unions, almost $100 \%$ of all potential voters participated in elections, huge number of people took part in demonstrations and followed political news. However, it was not voluntary participation, and not an evidence of their initiative and interest ${ }^{8}$. As soon as state pressure was eliminated, people lost their orientation, and their interest in politics fell sharply.

Table 2. To what extent are you interested in politics? (\%)

$\begin{array}{cclll} & \text { Significant } & \text { Medium } & \text { Insignificant } & \text { No interest } \\ \text { interest } & \text { interest } & \text { interest } & \\ 1994 & 9 & 28 & 34 & 28 \\ 1999 & 13 & 33 & 29 & 25\end{array}$

Source: Zorkaya, 1999, p. 15.

In 1990 the proportion of respondents who reported significant interest in politics was 2.5 times larger than in 1994 and the proportion of those who revealed insignificant or no interest was almost three times smaller (Zorkaya, 1995, p.20).

The figures can be better understood if one compares them with similar West German data (see Table 3). The figures of the last column of Table 2 are comparable with data for Germany in 1962. However, for Germany we have three levels of

\footnotetext{
${ }^{8}$ Apathy, lack of willingness to participate are mentioned as a characteristics of the people in communist countries in Brown, Archie, and Jack Gray, 1977, Political Culture and Political Change in Communist States. N.Y.: Holms and Meier (cited by Almond (1989)).
} 
interest instead of two in Table 2. Probably, some part of those who reveal "insignificant interest" would choose "no" in a three level scale. It is plausible that participation in contemporary Russia is close to Germany participation soon after the World War II.

Table 3. Political interest in Germany, 1952-77, \%

$\begin{array}{lllllll} & 1952 & 1959 & 1962 & 1969 & 1973 & 1977 \\ \text { Yes } & 27 & 29 & 37 & 45 & 49 & 50 \\ \text { Not especially } & 41 & 36 & 39 & 42 & 34 & 41 \\ \text { No } & \mathbf{3 2} & \mathbf{3 5} & \mathbf{2 4} & \mathbf{1 3} & \mathbf{1 7} & \mathbf{9}\end{array}$

Source: Conradt. 1989, p.239.

Table 4. Can most people be trusted? (Germany, percentage "yes")

$\begin{array}{lllll}1948 & 1959 & 1967 & 1973 & 1976 \\ 9 & 19 & 26 & 32 & 39\end{array}$

Source: Conradt. 1989, p.254

Social trust is an important precondition for social activity. The proportion of respondents who belonged to some voluntary organization grew in Germany from $44 \%$ in 1959 to $50 \%$ in 1967 , and $59 \%$ in 1975 .

It is remarkable that the indicators changed almost monotonically.

In a Russian survey of $1989,42 \%$ of respondents answered that they had "many intimate reliable friends". In 1999 this answer was chosen by $13 \%$ of respondents. In $199974 \%$ believed that they could completely trust merely two or three persons. (Levada, 2000, P. 26) ${ }^{9}$.

Lack of trust has direct economic consequence: it increases transaction costs and decreases investment (Zak and Knack. (2001)). 
Passivity entails comparatively low social and spatial mobility. It was found in Gromova (1998, p.26) that about $85-88 \%$ of respondents did not change their social groups during 1991-1993. The figure is equal to $93 \%$ for peasants, $92 \%$ for managers of the state sector, $89 \%$ for directors and workers, $87 \%$ for intelligentsia. The outflow is explained by retirements and by transition to the private sector. The inflow was zero for the group of directors, $2 \%$ for managers of the state sector, $1.5 \%$ for civil servants.

In accordance to a survey conducted by VCIOM in 1996 , only $15 \%$ of the respondents were ready to move from the a city where they lived to get a better job or life conditions, whereas the figure was $26 \%$ for Czech Republic, $29 \%$ for Poland, $30 \%$ for Bulgaria, $58 \%$ for USA. Russia ranks last by this indicator among 23 countries (Gudkov, 1999, p. 41). There is a substantial difference between West and East Germany (45\% and 37\%, correspondingly). Russia was also one of the last by rank in the proportion of people ready to go abroad to get a better job or living standards.

Another evidence of passivity is the small number of collective actions of protest. In spite of growing dissatisfaction, drop of living standards, and large wage arrears, the number of people involved in strikes has been insignificant $(357,000$ in 1992 , 120,000 in 1993, 664,000 in 1996) Out of 8,278 strikes taking place in 1996, 7,396 were in education ( Rossiyskii statisticheskii ezhegodnik, 1996; Sotsial'noekonomicheskoye polozheniye.., 1996). In fact, trade unions did not influence Russian economic life.

Difficulties in adaptation to the quick changes are another consequence of passivity. In 1999, more than one third of respondents answered that they were not able to adapt to the present changes, $16 \%$ stated that they just lived as they did before the reforms. Only 5\% said that they were now able to use new possibilities. In 1994, the figures looked rather better $-23 \%, 26 \%$, and 6\% correspondingly (Levada, 1999b, p.8).

It was expected that economic liberalization would free the entrepreneurial energy, the "animal spirit" that is thought to play so important role on the some early stages of capitalist development. However, this expectation was not realized. A possible cause is the legacy of the Soviet period. Real initiatives were punished in the past, therefore

\footnotetext{
${ }^{9}$ The data suggest an idea that trust (and, maybe participation as well) is an indicator of congruency of a culture and a socio-economic system. Then decrease of the trust level is an evidence of
} 
law-obedient people were passive, and did not experience self-organization. Dissidents had no popular leaders and qualified managers. Deviators like black market businessmen and criminals were the most active. The transition process gave them even more opportunities. Mass attitude towards official rules, legal norms and law enforcement institutions was the basis for their success.

\section{Attitude towards official rules, legal norms and law enforcement}

\section{institutions: habitual deviationism}

Those who preferred to be active in the USSR could chose between lobbying and deviant behavior. Lobbying was particularly developed by the enterprises. Directors traded with ministries for the enterprise plans. Their representatives, called "tolkachi", tried to convince officials to increase the enterprise supply by row materials (Kornai, 1980). Numerous restrictions resulted in efficiency losses and sometimes were incompatible so that their violation was inevitable. Every manager was forced to break rules to defend the interests of her/his collective.

A typical result of inefficient price policies was the overall shortage of goods and services. Huge volumes of goods were illegally resold, and black markets flourished, the informal exchange of priority services developed when, for example, a hairdresser and a meat seller served each other without standing in line. Another illegal equivalent of the priority service was the bribe system: an officer in a city council, a doctor in a hospital, a cashier in a theater box-office, took payments from the customers for the right to be served out of line. Millions of people were involved in these illegal or semi-legal activities as consumers or sellers. In most they undertook voluntary, and mutually beneficial contracts, and their behavior was not condemned too strong.

The state suppressed and prosecuted dissidents who were considered as heroes by a circle of Western-oriented intelligentsia. It added to the fuzziness of moral norms.

Rule evasion was transformed into a societal norm. This practice formed a special system of attitudes towards infringement of many official rules and legal norms, and

"misadaptation" and growing alianation. 
towards law enforcement institutions. I call this system "habitual deviationism" includes tolerant or even positive attitudes towards petty bribes, towards participation in black market operations, violation of registration rules ("propiska"), exam cheating, private use or even petty pilfering of the state property. A habitual deviationist does not like law enforcement institutions and hates those who cooperate with policemen or investigators. Disagreement with official political doctrines may be or may be not a part of these attitudes. Habitual deviationism does not always result in opportunistic behavior: a deviant may observe behavior norms that are different from the official ones.

Habitual deviationism creates an appropriate environment for more serious criminal activities. A bribe taker may behave as a partner or as an extortioner, and the boundary is very fuzzy. A person who breaks a law is highly susceptible to blackmail and can be used by criminal groups.

Fuzziness of moral norms became much stronger in the transition period. New legislation lagged behind the quickly changing practice, rules of the game were modified during the game. Many public organizations- hospitals, universities, research institutes- created private firms that employed the same personnel and used the same facilities. Many regional rules contradicted the federal legislation ("propiska" in Moscow, restrictions of regional good outflows, etc.). This made lawful citizen even more passive and facilitated the activities of criminal and semicriminal groups - the groups most prepared for the new environment.

In a survey of 1997, described in Haarland and Nissen, (1999), respondents were asked which factor was the most influential on the income level: personal achievements, personal connections, or a skill in evading laws. The results are presented in Table 5.

Table 5. Which factor is the most influential for the personal income, 1997 (\% of answers)

\begin{tabular}{|c|c|c|c|}
\hline Country & $\begin{array}{l}\text { Personal } \\
\text { achievements }\end{array}$ & Personal connections & Skill in evading la \\
\hline Poland & 48 & 39 & 13 \\
\hline
\end{tabular}




$\begin{array}{llll}\text { Czech } & 37 & 36 & 27 \\ \text { Hungary } & 37 & 48 & 15 \\ \text { Russia } & 30 & 34 & 37\end{array}$

Sourse: Haarland and Nissen 1999, p.16

The last column reveals a strong difference between Russia and other countries.

In 1999 a survey was conducted in the framework of the International Social Science Programme. Respondents were asked to what degree they agreed with the following statement: "In contemporary Russia it is necessary to give and to take bribes if one wants to rise somewhat "on top". $40 \%$ of respondents were completely agreed and 34\% were rather agreed with the statement. (Khakhulina, 1999, p. 29).

In December 1999 survey, Russian respondents were asked: "Do you agree that it is not obligatory to pay taxes?" $31 \%$ were "rather, agreed" and 59\% were "rather, did not agree". However, the figures were, correspondingly, $62 \%$ and $32 \%$ for main Russian taxpayers, businessmen, and $21 \%$ and $68 \%$ for pensioners who did not pay taxes at all.

In a survey of March 1999, 56\% of respondents declared that "it is extremely reprehensible to take something out of an enterprise (i. e., steal), but $31 \%$ found that "it is partly reprehensible". 22\% saw "nothing reprehensible" in purchasing goods that were taken out of an enterprise, and $31 \%$ considered this as "partly reprehensible”.(Levada, 2000. PP. 21-23).

Fuzziness of laws entails broad possibilities of their interpretation. Since the law is incongruent to reality many people are forced to break it. This implies the selectivity of law enforcement. The fuzziness and selectivity both create a base for arbitrariness of the judicial decisions and, therefore, for political use of the law enforcement institutions. Unsurprisingly, the degree of people's trust in these institutions is very low (see Table 6).

Table 6. Do you trust the people of the following professions? (The ratio of responding "yes" to the number of answering "no", 1993)

$\begin{array}{lllllllll}\begin{array}{l}\text { Profes } \\ \text { sion }\end{array} & \begin{array}{l}\text { Scien } \\ \text { tist }\end{array} & \begin{array}{l}\text { Cleri } \\ \text { cal }\end{array} & \begin{array}{l}\text { Doc } \\ \text { tor }\end{array} & \begin{array}{l}\text { Busi } \\ \text { ness } \\ \text { man }\end{array} & \text { Judge } & \begin{array}{l}\text { Police } \\ \text { man }\end{array} & \begin{array}{l}\text { Offi } \\ \text { cial }\end{array} & \begin{array}{l}\text { Politi } \\ \text { cal } \\ \text { figure }\end{array} \\ \text { "yes"/ } & 19.0 & 9.5 & 4.7 & 1.2 & 0.5 & 0.2 & 0.2 & 0.07\end{array}$


"no"

Source: Gudkov.2000, p.31

Only politicians and officials have lower credibility than policemen and judges.

In a survey of 1998 respondents were asked "To what extent do you trust the judicial system and law enforcement bodies?" There were 30\% who answered "very little" and $27 \%$ - "absolutely do not trust". As a result of the distrust, only less than $10 \%$ of victims of criminal cases apply to the police. This explains why the number of registered crimes is less in Russia than in some developed countries (1634 per 100 thousand of inhabitants in comparison to 7700 in Germany in 1997). However, the number of prisoners per capita is enormously high (nine times larger than in Germany) (Gudkov.2000, pp.35, 37).

Arbitrariness of low enforcement bodies and popular apathy are unfortunately connected by positive feedback. In accordance to a survey of 1996, only $13-15 \%$ of respondents declared their readiness to collective action if their rights were violated. (Gudkov, 2000, p.38). This was merely intention, however. In fact, the number of protest actions were insignificant (see Levada, 1999, p.10, and Section 4 above).

The lack of credibility of law enforcement bodies could explain why people refuse to cooperate with the bodies, and do not inform them about crimes observed (leaving aside criminal offences such as murders or robberies). However, the situation is even worse: the informers are condemned and hated. As plausible reasons one can mention historical memory about Stalin's era of informers, lack of believe that the information will be used effectively and fairly, and a collective self- protection: informers are enemies of a collective whose members break the law regularly.

In our survey of 2000 , devoted to people attitudes towards petty corruption, the following situation was described: "Citizen A suggested payment to official B to accelerate registration of A's inheritance. Official B agreed. Official C reported the case to the head of the department." The respondents were asked to characterize their attitudes towards citizen A and officials B and C using a five-points scale (Table $7 a)$.

Only $32 \%$ of respondents condemned citizen A, who initiated the bribe. Negative or strongly negative attitudes towards the informer were revealed by $59 \%$ of 
respondents. Slightly more than a half of them (53\%) disapproved and a rather large group (15\%) supported the briber.

Similar attitudes towards A and B were revealed in a survey of 2002 (Table 7b). The respondents were Russian students. Their attitude towards informer $\mathrm{C}$ is less negative than in the previous survey. However, attitudes of Israel students (Table 7c)

Table 7a. Attitudes towards bribe-giver A, bribe -taker B, and informer C

Russia, 2000

(percentage of respondents and average evaluations; $\mathrm{N}=74$ )

\begin{tabular}{|l|l|l|l|}
\hline Attitude & $\begin{array}{l}\text { Towards citizen A } \\
\text { (suggested payment } \\
\text { to B) }\end{array}$ & $\begin{array}{l}\text { Towards official B } \\
\text { (agreed to take } \\
\text { payment from A) }\end{array}$ & $\begin{array}{l}\text { Towards official C } \\
\text { (reported the case) }\end{array}$ \\
\hline 1.Strongly negative & 0.04 & 0.11 & 0.27 \\
\hline 2.Negative & 0.28 & 0.42 & 0.32 \\
\hline 3.Neutral & 0.45 & 0.32 & 0.15 \\
\hline 4. Positive & 0.18 & 0.11 & 0.18 \\
\hline 5. Strongly positive & 0.05 & 0.04 & 0.8 \\
\hline Average evaluations & -0.08 & -0.45 & -0.52 \\
\hline
\end{tabular}

Average evaluation is defined as 2(line 5) + line 4- line 2- 2(line 1).

Table 7b. Attitudes towards bribe-giver A, bribe -taker B, and informer C .

Russia (students), 2002, (percentage of respondents and average evaluations; $\mathrm{N}=84$ )

\begin{tabular}{|l|l|l|l|}
\hline Attitude & $\begin{array}{l}\text { Towards citizen A } \\
\text { (suggested payment } \\
\text { to B) }\end{array}$ & $\begin{array}{l}\text { Towards official B } \\
\text { (agreed to take } \\
\text { payment from A) }\end{array}$ & $\begin{array}{l}\text { Towards official C } \\
\text { (reported the case) }\end{array}$ \\
\hline 1.Strongly negative & 0.06 & 0.30 & 0.17 \\
\hline 2.Negative & 0.11 & 0.25 & 0.32 \\
\hline 3.Neutral & 0.55 & 0.26 & 0.17 \\
\hline 4. Positive & 0.26 & 0.17 & 0.20 \\
\hline 5. Strongly positive & 0.02 & 0.02 & 0.14 \\
\hline Average evaluations & 0.07 & -0.64 & -0.18 \\
\hline
\end{tabular}


Average evaluation is defined as 2(line 5) + line 4- line 2- 2(line 1).

are quite different from Russian ones: more negative to bribe-giver and bribe-taker and positive to informer.

Table 7c. Attitudes towards bribe-giver A, bribe -taker B, and informer C

Israel (students), 2002

(percentage of respondents and average evaluations; $\mathrm{N}=25$ )

\begin{tabular}{|l|l|l|l|}
\hline Attitude & $\begin{array}{l}\text { Towards citizen A } \\
\text { (suggested payment } \\
\text { to B) }\end{array}$ & $\begin{array}{l}\text { Towards official B } \\
\text { (agreed to take } \\
\text { payment from A) }\end{array}$ & $\begin{array}{l}\text { Towards official C } \\
\text { (reported the case) }\end{array}$ \\
\hline 1.Strongly negative & 0.28 & 0.56 & 0.12 \\
\hline 2.Negative & 0.24 & 0.28 & 0.16 \\
\hline 3.Neutral & 0.32 & 0.12 & 0.24 \\
\hline 4. Positive & 0.16 & 0.04 & 0.24 \\
\hline 5. Strongly positive & - & - & 0.24 \\
\hline Average evaluations & -0.64 & -1.36 & 0.32 \\
\hline
\end{tabular}

Average evaluation is defined as 2(line 5) + line 4- line 2- 2(line 1).

Habitual deviationism reveals itself in all spheres of the Russian social life. An example is students cheating that is quite typical at all levels of education. Here, unwillingness to cooperate with authorities reveals itself in a full measure.

The following situation was described in a questionnaire (Magnus, Polterovich, Danilov, Savvateev, 2001): Student C reports to the departmental office that student A, while taking an exam, copied answers from student B's paper with the consent of student B. Respondents were asked to evaluate their attitudes towards each A, B, and $\mathrm{C}$ on a 5-point scale: strongly negative (-2), negative (-1), neutral (0), positive (1), strongly positive (2). The sample includes 506 students studied in Russia, 247 -in Netherlands, and 112-in USA. Table 8 contains average evaluations. 
The results revealed substantial differences in attitudes ${ }^{11}$. Russian students are much more tolerant to cheater $\mathrm{A}$, support assistant $\mathrm{B}$, and hate informer $\mathrm{C}$; their evaluation of $\mathrm{C}$ is not far from the minimum (-2). USA students are much more tolerant to the informer. In fact, many of them revealed positive attitude to C.

Table 8. Attitudes to cheating (average evaluations )

\begin{tabular}{|c|c|c|c|}
\hline & $\begin{array}{l}\text { A } \\
\text { (copied answers } \\
\text { from B's paper) }\end{array}$ & $\begin{array}{l}\text { B } \\
\text { (gave her/his } \\
\text { consent to A) }\end{array}$ & $\begin{array}{c}\mathrm{C} \\
\text { (reported the case) }\end{array}$ \\
\hline Russia & -0.21 & 0.54 & -1.73 \\
\hline Netherlands & -0.83 & -0.05 & -1.36 \\
\hline USA & -1.35 & -0.88 & -0.25 \\
\hline
\end{tabular}

Source: Magnus, Polterovich, Danilov, Savvateev ( 2001).

It is important to stress that many respondents not only reject well-known norms of behavior but support alternative norms.

Habitual deviationism, disinclination to cooperate with law enforcement bodies, make it probable that radical liberal reforms can bring an economy to a stable inefficient equilibrium where criminal activity, black market, tax evasion, and corruption prevail.

\section{Workers' collectivism and "social responsibility" of managers}

One of the consequences of Soviet paternalism was a special role for work collectives. The state partially delegated the distribution of many goods and services to the enterprise level. This included apartments, dachas, cars, kindergartens, sport facilities, health and holiday services, and even food and cloth. Stimulating schemes connected performance indicators of an enterprise and wage rate of its workers. In the late eighties many enterprise directors were elected by the members of their collectives. This created a spirit of interdependence and solidarity. Such a feature of the cultural legacy substantially influenced privatization processes, stimulated labor hoarding, and slowed down enterprise restructuring. In a survey of $1993,58 \%$ of

\footnotetext{
${ }^{11}$ Disinclination to cooperate with power is not a unique explanation. Attitude towards competition might be important as well. The difference in tolerance to cheating may depend also on designs of
} 
enterprise managers declared that one of their main purpose was to preserve their enterprise collectives. (Dolgopyatova, 1995, p.85). In surveys of The Russian Economic Barometer, about $65 \%$ respondents (managers) pointed out "social responsibility" as a main cause of labor hoarding. In all samples of 1995-1999, this answer was given much more often than any other response (Kapelushnikov, 2001, p.217). Explaining similar findings, Linz argued that they are caused, at least partially, by a paternalistic belief that "everybody has a right for a job" (Linz, 1998).

\section{Attitude towards foreigners}

In 1998 VCIOM conducted a number of surveys in framework of the International Social Survey Programme (ISSP). Some results were published in Dubin (1999). About 48\% of Russian respondents (from the total number of nearly 1700) thought that "Western culture has had a negative impact on Russia". Only 20\% agreed that "in total, immigrants affected our economy positively" ( 63\% for Canada, 37\% for Poland, and only $9 \%$ for Hungary, and $8 \%$ for Czech Republic. It is quite possible that the lack of selective immigration policy influenced the answers.) About $72 \%$ of the respondents "in total, did not trust Western businessmen", and $80 \%$ of them are confident that "for foreigners, it has to be forbidden to buy land in our country". By this indicator, Russia is the second among 23 countries after Bulgaria (81\%). All East European countries occupy the upper part of the list; the figures are $71 \%$ for Latvia, and 59\% for Poland, against 33\% for USA and $16 \%$ for East Germany (Dubin, 1999, pp. 39, 46).

The lack of foreign investments in Russia is usually explained by economic and political instability, high uncertainty, and low quality of governance. It would be interesting to investigate however, to what extent the attitude toward foreigners affects the volume of FDI.

\section{Attitude towards market institutions}

“ The market economy is complicated and fills people with fear of the future". About $60 \%$ of Poland and Czech respondents and about $75 \%$ of Hungary and Russia respondents agreed with this statement in a 1997 survey (Haarland and Nissen 1999, p.16).

educational systems. 
More surprisingly, the proportion of people, who disapproved reforms, was larger in 1999 than in 1992 or 1993 (Table 9). In accordance to a survey of 2001, price liberalization and transition to market economy in 1991-1992 were negatively evaluated by $54 \%$ of respondents, and $85 \%$ of the respondents disapproved voucher privatization of 1992-1993 (Zdravomyslov, 2002, p.53).

Table 9. Many people say it would be better if everything in this country remained as it had been prior 1985. Do you agree or disagree with this statement? (Percentage of respondents)

\begin{tabular}{|l|l|l|l|}
\hline & 1992 & 1993 & 1999 \\
\hline Agree & 45 & 46 & 58 \\
\hline Disagree & 39 & 30 & 27 \\
\hline
\end{tabular}

Source: Levada, 1999a, p. 20.

\section{Attitude towards democratic institutions and liberal values}

In most transition countries economic and political orientations of a person seem to be strictly connected. For most people the democracy and the free market are strongly associated, since both are Western-type values and mechanisms and both are antagonists of a Soviet- type socio- economic organization. The economic reform is the main issue of the political debate, a core of party political programs. Mass attitudes toward property, competition, and income inequality are closely related to prevailing political culture.

It is well known that credibility of government is an important factor of reform success. Therefore the attitude toward governments and governance mechanisms that 
are standard elements of the political culture have strong impact on economic performance.

Another kind of potential connections between political and economic culture could be rooted in the influence of political regime on the economic outcome. However, a number of recent investigations did not reveal direct connections between political regimes and economic growth (World Development Report, 1997). What was found to be important is governance quality (Stiglitz, 1997; Shleifer, 1997; Olson, Sarna, Swami, 1998).

In a survey of 1998 reported by Dubin (1999), about 31\% of respondents agreed that "democracy is harmful for Russia", and about $56 \%$ of respondents thought that "principles of the Western democracy are incompatible with Russian traditions". (Dubin (1999), p.39). This corresponds to the answers on a question that was asked in another survey of the same program in 1996: "Are you honored by democratic institutions of your country?" Among 23 countries, the percentage of the affirmative answers was the lowest in Russia (20\%). One should note that the bottom part of the list was occupied by nine East European countries and Italy (the sixth from the bottom). The highest number out of the ten belongs to Czech Republic - 35\%. In

Ireland, Canada, Netherlands, USA, Norway the figures amount of 85-80\% (Gudkov (1999), p. 43).

Haarland and Nissen (1999, p.17) asked respondents in 1997 whether they agreed with the statement "Democracy unavoidably entails chaos and anarchy". The proportion of "yeas" was 37\% for Poland and Czech, 30\% for Hungary, and $66 \%$ for Russia.

The results indicated that Russian democracy was appeared highly unstable, and that Russia might move to a more authoritarian and more paternalistic system of governance.

\section{Manipulability}

A politician has two strategies to attract voters. She can invest in political projects that are potentially useful for her voters. Or she can invest in political advertisement to create her image. We say that a voter is highly manipulable if she is sensible to advertisement and does not like to evaluate political programs and projects. High 
manipulability creates incentives not for positive discussions but for spending resources to win advertisement contest (Hillman, Ursprung (1998)).

High manipulability seems to be a cause of the fast and unmotivated changes in the Russian public opinion during the election companies of 1996 and 1998. Only 6\% of population believed Yeltsin in December, 1995. The figure increased to 22\% in July, 1996 (Zorkaya, 1999a). During two months political block "Edinstvo" increased the number of its supporters from 4.3\% (in October 1999) to 21.1\% (in December 1999). In both cases political leaders did not present any program or projects. The effects were reached merely by intensive advertisement campaigns, by the struggle of personal images and slogans.

Democratization may give rise to imperfect democracy due to people passivity, unwillingness to participate, and mass manipulability. This kind of a democratic mechanism does not help to reveal true preferences of the people, to find consensus, and to make effective decisions. It rather turns out to be a field of exhausting battles and costly lobbing as well as an instrument of manipulation of the public opinion.

\section{The culture of governance}

In a number of recent investigations it is established that the quality of governance is an important determinant of economic growth. Olson, Sarna, and Swamy used five indicators from the International Country Risk Guide to measure the quality of governance: the risk of expropriation, the risk of repudiation of contracts by government, corruption in government, quality of bureaucracy, and rule of law, as well as an aggregate of this five variables. They considered a sample of 68 countries for the years 1960-1987 and found that all variables and their aggregate were significant to explain the variation in the rates of growth of productivity across countries. (Olson, Sarna, and Swamy, 2000). A similar conclusion was reached earlier in Knack and Keefer (1995). Schleifer compared indicators of legal and regulatory environment for Moscow and Warsaw and came to the conclusion "that the Russian government is less effective in serving the market economy -as well as its 
people- than the Polish government" " but the exact cause of poor government performance is difficult to pin

down". Shleifer rejected cultural arguments "such as low trust ${ }^{12}$ and anti-market culture", and recommended "to accelerate elections on the sub-regional or local levels", to develop fiscal federalism, and to continue institutional reforms. (Shleifer, 1997).

Today, when paternalistic pressure strengthens in Russia and the demand for "the strong hand" rises ${ }^{13}$, one should have less hope that the situation may be substantially improved by new elections. A return to the cultural analysis seems to be more fruitful. I have no systematic data to compare the Russian and East European civic cultures. However, I will try to outline some arguments and hypotheses that make a cultural explanation plausible. ${ }^{14}$

First of all, the culture of the governing elite is strongly connected with the mass culture. This is confirmed in Levada (1998). Levada used data of 1994-1997 to compare attitudes of leaders and specialists with attitudes of a typical respondent in the sample. He has found that a representative of the social elite had a little bit larger wage, was more educated, had more positive attitude toward reforms. Nevertheless as well as an average person, she required stronger state power. More than $90 \%$ of the elite believed that the state should guarantee a minimal subsistence level and a job to everybody. Levada mentioned paternalist expectations as a characteristic feature of both- a representative of the elite and a person from the street (pp.17, 18).

Two inherited features considered above- paternalism and habitual deviationism are particularly important for understanding of Russian governance.

A paternalistic governor ignores people attitudes for two reasons. He is sure that he knows the people needs better than the people themselves, and he does not expect serious resistance from the masses since they are passive and are not able to self-

\footnotetext{
${ }^{12}$ The rejection was based on the results of a survey. The survey has shown that Russian index of participation was much lower than in most developed countries or China but higher than Hungarian or Romanian ones. The Russian trust index was in the middle. In the survey, however, "participation" did not include political, trade union, or religious activities. Besides, the trust and participation depend on possibilities to participate and, therefore, on the reform process itself. In Russia the trust indicators decreased during the reforms.

${ }^{13}$ In a speech of 2001 President Putin said: "As a President, I am responsible for all events that happen in Russia."
} 
organization. If any resistance occur, he tries to suppress it rather than to search for a compromise. In fact, he is a follower of the communist philosophic doctrine that "struggle of opposites is the moving force of development" and accepts a slogan of the Stalin regime " those who not with us are against us". A paternalistic governor thinks by extremes, and makes no efforts to find more sophisticated interim solutions. She does not admit that her opponents could be right at least partially, and uses political debates and voting procedures to win a battle. This authoritarian style operating in a democracy can be seen as an extreme case of adversarial system of governance; the concept was introduced recently in Stiglitz (1998) ${ }^{15}$.

Stiglitz confronts the adversarial and consensus systems of governance. Consensus governance relies on an open dialogue and on some shared conception of the national interest. Consensus-based system increases ability of government and political agents to make stable commitments and eliminates or, at least, softens destructive competition. Reaching consensus in a democratic and open way is a process that merits to be valued in its own right.

It is not a surprise that that communist parliamentarians and governors, direct successors of the Soviet political practice, followed the adversarial strategies. More distressing, reformers inherited the same style.

Russian reforms were much more radical than reforms in East European countries if one take into account initial conditions. The radicalism implied large social costs and deep dissatisfaction. During the year following price liberalization Bulgaria experienced a consumption price shock of $339 \%$, Poland- $249 \%$, Romania - 223\%, Czechoslovakia - 54\%, Hungary - 32\%. Expected inflation rates were correspondingly $234 \%, 94 \%, 104 \%, 30 \%$, and 31\%. (Bruno, 1993, p.220).

In accordance to the Russian program, the expected inflation rate was $250-350 \%$. This was reached during the first month. The first year consumption price shock was 2600\%. People's savings disappeared in a moment.

\footnotetext{
14 Shleifer seemed to be agree with two important cultural arguments that influenced the difference in performance of Poland and Russia: traditions of democracy and free markets in Poland, and a critical role of the Catholic Church and the Solidarity Labor Union.

${ }^{15}$ Stiglitz write: “... the adversarial system is based on debates which is more for public consumption than an attempt to forge common ground for a consensus." The objective of each party "is not to craft a proposal that minimizes the inevitable risk associated with new policy, but to win a victory in the political process.” (Stiglitz, 1998, p.19). Stiglitz criticized Clinton administration for its adversarial system of governance. We use the term "adversarial governance" in the Russian context to denote authoritarian, confrontationist style that is realized through voting or other democratic procedures as well as through manipulation of judicial system to reach political goals.
} 
Russian privatization was also one of the most wide-scaled and quick. During a year and a half, about $70 \%$ of industrial enterprises were privatized. One should take into account that, at the start of privatization, worker collectives considered their enterprises as their own property (Polterovich, 1995). From their point of view privatization was not merely voluntary transmission of the de jure state property to other owners but also an attempt to expropriate the de facto collective property and pass it to outside investors. The exhausting struggle between the government and worker collectives resulted in the government defeat: most of enterprises retained in hands of insiders.

The reformers relied on the theory of the "minimal state", tried to minimize social expenditures, rejected importance of industrial policy, and did not pay enough attention to regulation problems. People turned out to be unprotected against risky bank policies and financial pyramids. An important principle of consensus governance - a looser has to be compensated - was for the most part ignored.

Whether a norm is enforceable depends on the prevailing system of norms and attitudes. However an adversarial government tries to enforce a "good" norm by introduction of additional restrictions. Typically, this makes the situation even worse since more people find it impossible to respect all requirements. Thus, Russian government introduced more and more complicated tax system to combat tax evasion. This resulted in even more severe tax evasion. I think that an open dialogue could be much more useful but its precondition should be the tax discipline of the elite itself.

At the governance level, habitual deviationism involves inability to make commitments. The Russian government did not fulfill its obligations permanently. The most striking examples are wage and pension arrears and delays in financing of the public sector. This policy created strong impulses for development of arrears crises. A paradox, the policy was directed to suppress inflation but contributed, maybe stronger than inflation, to economic uncertainty and the government discredit.

The second consequence of rule evasion was a wide-scaled use of public positions for private purposes. By the Corruption Perception Index, Russia was ranked as $47^{\text {th }}$ among 54 countries in 1996 and took the $76^{\text {th }}$ place in a list of 85 countries in 1998 (Tanzi (1998)). Recently, a composite index of state capture was constructed for twenty transition economies on the base of Business Environment and Enterprise Performance Survey (Hellman at al (2000)). The index is the average proportion of 
firms reporting that each of the following components of grand corruption is a problem: the sale of Parliamentary votes or Presidential decrees, capture of the Central Bank, sale of arbitration or criminal court decisions, and non-transparent political party financing. Russia takes $17^{\text {th }}$ place after Bulgaria and Georgia, and before Moldova, Ukraine, and Azerbaijan.

The third consequence of the habit of rule evasion was numerous violations of the democratic norms of the political contest and the governance.

Aleksander Korzhakov, a chief of the Yeltsin's guard, was one of the most influential figure in 1994-1995. He tried to give orders to the Prime Minister and, in 1998, publicly argued that the coming President elections should be abandoned.

In contemporary Russia, the judicial system is widely used to reach political goals. Almost every prominent entrepreneur or political figure may be a subject of investigation due to law fuzziness and habit of rule evasion. In 1996, the chief of The Federal Security Service announced investigations with respect to 500 officials of high rank including 50 top rank officials. Two or three such persons were convicted (Gudkov, 2000, p.33). Prominent people may be arrested and dismissed without plausible explanations though the semblance of the law is observed (the more recent examples are a mass media magnate Vladimir Gusinsky and an "aluminum king" Anatoly Bykov). In June 2000, the General Procurator's Office attacked a number of so called "oligarchs" (major bankers and businessmen), and then closed the cases.

During nine years of the reforms Russia has been a field of severe battles between Parliament and President. Describing his government activity, Egor Gaidar directly uses military terminology:

“... In May of 1992 the government retreated under onslaughts of superior forces and fought rear-guard actions..." (Gaidar, 1996, p. 203).

In 1993 this war resulted in shelling of the parliament by the government tanks. After a short time reformist Gaidar's party lost parliament elections.

Thus, the culture of the Russian governing elite is strongly connected with mass culture and is characterized by two inherited features: paternalism and the habit of rule evasion. A consequence of the paternalism is the authoritarian style of operating in a democracy - an extreme case of adversarial system of governance that involves very high transaction costs. It may be contrasted with the consensus system of governance that relies on an open dialogue and on some shared conception of the 
national interest, which increases the ability of government to make stable commitments and softens destructive political competition.

At the governance level, habitual deviationism involves inability to make commitments, a wide-scale use of public positions for private purposes, and numerous violations of the democratic norms of the political contest.

Paternalism and habitual deviationism have left their imprint on the cultural particularities of the new Russian power elite. Its radicalism, lack of managerial skills, inability and reluctance to search for compromise settlements, and its corruptibility, entailed a high probability of ineffective governance including serious mistakes in choice for the reform design.

\section{Consensus governance and interim institutions}

The main difference between shock therapy and gradualism is not the speed of reforms itself but a methodology to transplant market institutions. Gradualism suggests that a new system has to be built through a sequence of interim institutions that facilitate appropriate modification and adaptation of the new rules and norms. An impressive example of an interim institution is Chinese dual-track system (Roland, 2000). A widely used but a little bit vague concept of "initial conditions" includes not only cultural and macroeconomic indicators but also the quality of interim institutions that were built at the preparatory stage of the reform. Taking into account initial conditions, one has to conclude that reforms, conducted in the successful East European countries, were much more gradual than the Russian reforms.

First, these countries had more substantial legal, political, and economic traditions that retained in social memory since, at the start of the reforms, about $20 \%$ of population were born in the pre-communist era ${ }^{16}$. Second, Hungary and Poland had much more developed quasi-market institutions. Before 1989 Hungary put in place a two-tier banking system, a tax reform, and a corporate law. By 1982 over 50\% of consumer goods were free of control, the percentage gradually increasing to over $90 \%$ in 1991. At the start of the Polish reform in 1990, this country had a well- established private sector in agriculture, trade, services, and construction. More than one third of

\footnotetext{
16 It is also important that the East European societies were much more consolidated by the idea to build independent states and to join Western civilization. By contrast, Russia experienced deep national crisis because of the USSR disintegration and decreasing role of Russia in the world.
} 
the Polish labor force was employed by private firms and produced a quarter of national output. Among communist countries, Czechoslovakia had the most developed industrial structure, a small monetary overhang, and extremely low external debt-to- GNP ratio (Bruno, 1993, pp. 211-213). The differences in the strength of the initial price shock, mentioned above, were caused by initial conditions.

Thus, the governing elites of East European countries were more skillful in the choice of suitable sequences of interim institutions at the pre-reform stage. It does concern the reform stage as well, and first of all, the system of losers' compensation including social and industrial policies.

Social policy is a standard device to reach a consensus through the compensation of losers. In Hungary, Poland, and the Czech Republic, comparatively fast restructuring was positively effected by possibilities of early retirement and high pension levels. (Commander, McHale, and Yemtsov, 1994). The same measures were used during an administration reform in China in 1983. A large section of old-minding bureaucrats was forced to retire. However they got high pensions and kept their cabinets and access to the government information they had before retirements $(\mathrm{Li}, 1998)^{17}$.

The importance of social policy is recognized now by many researchers. It is much less understood that industrial policy may also serve as important instrument to reach consensus. As Cazes observed, French indicative planning was not only a means to coordinate state and private business efforts, but also an opportunity to organize a discussion among different groups of population (Cazes, 1990).

In a survey of 1999, conducted by World Bank and EBRD, firms from 20 transition countries were asked how often the state directly intervenes in firm's decision on sales, prices, wages employment, and investment. (Hellman and Schankerman, 2000). Responses comprised always, mostly, frequently, sometimes, seldom, never. A composite index of state intervention was calculated as average (by all five types of decisions) proportion of firms that gave one of the first four answers (i.e., sometimes or more often). Table 10 contains some results of this study. We selected 9 "most successful" transition economies, that had largest ratios of GDP in 1999 to GDP in 1989, and compared them to Russia. It turns out that only three countries-Estonia, Groatia, and Poland- have composite index smaller than Russian one. Estonia is the

\footnotetext{
${ }^{17}$ About role of social expenditure as a prerequisite and a factor of growth see McCallum and Blais (1987) and World Development Report (1997).
} 
only country where the state intervenes in the firm's investment decisions less frequently than in Russia. The same study contains data on proportion of firms that were subsidized by central or local governments. This proportion is less than in Russia only for two countries- Estonia and Poland.

The cited study provides evidence that industrial policy was important for the success of transition. I believe that its direct economic effect was mixed. However, the direct effect is not an appropriate indicator for this case. Social and industrial policies both were necessary to soften the consequences of social and economic shocks and to facilitate adaptation to the new conditions for people and economic agents. They were necessary to maintain dialogue between the state and citizens.

Table 10. Government intervention in the firm decisions: nine most successful transition economies and Russia

\begin{tabular}{|l|l|l|l|l|l|l|}
\hline No & \multicolumn{1}{|c|}{$\mathbf{1}$} & \multicolumn{1}{|c|}{$\mathbf{2}$} & \multicolumn{1}{c|}{$\mathbf{3}$} & \multicolumn{1}{c|}{$\mathbf{5}$} & \multicolumn{1}{|c|}{} \\
\hline & Country & $\begin{array}{l}\text { Composite } \\
\text { index of state } \\
\text { intervention } \\
\text { (\% firms) }\end{array}$ & $\begin{array}{l}\text { Intervention } \\
\text { to } \\
\text { Investment } \\
\text { decisions } \\
\text { (\% firms) }\end{array}$ & $\begin{array}{l}\text { Subsidies } \\
\text { (\% firms) }\end{array}$ & $\begin{array}{l}\text { Subsidies } \\
\text { and other } \\
\text { transfers } \\
\text { \% GDP }\end{array}$ & $\begin{array}{l}\text { GDP \% } \\
\mathbf{9 9 / 8 9}\end{array}$ \\
\hline 1 & Estonia & $\mathbf{1 1 , 8}$ & 10,2 & 10,7 & 16,0 & 79,0 \\
\hline 2 & Croatia & $\mathbf{1 5 , 8}$ & 18,4 & 14.4 & $18,4 *$ & 77,8 \\
\hline 3 & Poland & $\mathbf{1 6 , 4}$ & 17,3 & 11,6 & 20,4 & 121,8 \\
\hline $\mathbf{4}$ & Russia & $\mathbf{2 1 , 8}$ & $\mathbf{1 5 , 9}$ & $\mathbf{1 3 , 7}$ & $\mathbf{1 5 , 2}$ & $\mathbf{5 7 , 8}$ \\
\hline 5 & $\begin{array}{l}\text { Czech } \\
\text { Republic }\end{array}$ & $\mathbf{2 3 , 4}$ & 23,7 & 13,9 & 27,9 & 94,8 \\
\hline 6 & Slovenia & $\mathbf{2 9 , 8}$ & 23,1 & 11,5 & 20,3 & 105,5 \\
\hline 7 & Uzbekistan & $\mathbf{3 4 , 3}$ & 28,7 & 15,2 & - & 93,9 \\
\hline 8 & Hungary & $\mathbf{4 3 , 9}$ & 37,9 & 23,3 & 19,3 & 99,3 \\
\hline 9 & Belarus & $\mathbf{5 2 , 2}$ & 32,6 & 27,2 & 18,4 & 81,4 \\
\hline 10 & Slovakia & $\mathbf{5 4 , 2}$ & 52,2 & 14,4 & 22,3 & 100,5 \\
\hline
\end{tabular}

Sources: Hellman and Schankerman, 2000, pp.560, 569; Economic Survey of Europe, 2001, pp. 254, 89.

* Data of 1998 . 
This point of view is supported also by macroeconomic data on subsidies and other current transfers as percentage of GDP. For all nine countries this percentage was larger than in Russia (see Table 10, column 5).

The Russian reform story shows that the skill of the governing elite to choose an appropriate form and level of state intervention is an important indicator of quality of governance and civic culture in general.

\section{Civic culture and transformational recession}

Trying to explain transformational recession, many authors stress the role of institutions. One has to explain, however, why and in what sense were institutions in Poland, Estonia, and Uzbekistan better than in Russia. Comparisons give rise to hypothesis that civic culture is important but it is not the only factor that influences different indicators of institutional quality used by many authors. There are at least two others: initial distortions and strategy of the reforms.

Many indicators of institutional quality measure, in fact, intensity of criminal and semi-lawful redistributive behavior of economic agents and the ruling elite (see Aron, 2000). Evidently, the intensity depends on the inclination of citizens to observe official norms, on their trust to each other and to political institutions, on their ability to adapt positively to the market reforms. All of these are features of civic culture. However the culture defines only a potential of the redistributive activity. The actual activity depends on volume, accessibility and attractiveness of rent released due to reforms.

If initial price distortions are high then price and foreign trade liberalization may release a huge volume of rent. The same is true for privatization if the property is highly undervalued. If government refuses to extract the rent the reforms stimulate rent-seeking activity. The scale and the forms of the activity depend on the civil culture prevailed. The struggle for the rent may look as organized lobbing in the parliament or as bloody battles among criminal groups.

In Russia of 1992, domestic prices of oil, fuel and non-ferrous metals were tens and hundreds times lower than world prices. Large enterprises were undervalued hundreds and thousands times. Under this conditions there were no any sense to 
invest into production: all resources should be invested into rent-seeking. Bureaucrats redistributed not merely state revenue, but the whole state property. Their power strengthened drastically, but their official wage rates fell. That was a field for flourishing corruption. Redistributive coalitions, criminal and semi-criminal ones turned out to be the most active part of population. The majority was passive and had no civil organizations to resist. Aslund (1996) estimates gross income from rentseeking activity in 1992 as $80 \%$ of Russian GDP. It is not clear how to estimate lives of thousands Russian new businessmen who were killed in the battles for the rent.

Thus, we suggest an explanation of transformational recession as a result of interaction of three factors: initial distortions, civic culture, and strategy of reforms.

There are many evidences that all three factors were comparatively favorable for such countries as Hungary, Czech Republic, Slovakia, Slovenia, Poland.

Most of former Soviet Republics had strong distortions and weak civil society. Among them, Uzbekistan suffered from reforms less than others did, since strong political control and gradual reform's strategy held rent-seeking activity in check. ${ }^{18}$

In Katyshev, Polterovich, 2002, we tried to follow this explanation. We took into account three explanatory variables of the output fall: export in non-CMEA countries as a percentage of official GDP, shadow GDP as a percentage of total GDP, and speed of privatization. The data were available for 16 transition economies (Table 11). For each country we define the year of reform's start (column 3). Export and shadow GDP were taken for the pre-reform year from de Melo at al (1997) and Johnson at al (1997), and speed of privatization was calculated as increment of a privatization index (de Melo at al (1995)) for three years after the reform's start.

Export was considered as a proxy for distortions: the larger export share the less distorted has to be the economy. ${ }^{19}$

It is difficult to hold rent seeking in check under fast privatization. Therefore the speed of privatization is assumed to have negative influence on output.

A percentage of shadow GDP in the total GDP is also an indicator of distortion. The same time, it characterizes civic culture prevailed. Large shadow economy means that many people do not respect law and do not trust governing bodies.

\footnotetext{
${ }^{18}$ An interesting comparison of Uzbekistan gradual policy and Kyrgyzstan shock therapy is given in Fridman, 2001, pp.83-120. The losses from shock therapy turned out to be higher.

${ }^{19}$ This proxy is not very appropriate for Russia since oil, gas, and minerals amount to the most part of its export.
} 
Table 11. Transformational recession: GDP and explanatory variables

\begin{tabular}{|c|c|c|c|c|c|c|}
\hline \multirow[t]{3}{*}{$\mathbf{N}$} & Country & $\begin{array}{l}\text { Year of } \\
\text { reform's } \\
\text { start }\end{array}$ & $\begin{array}{l}\text { Average } \\
\text { GDP as a } \\
\text { percentage } \\
\text { of pre- } \\
\text { reform GDP }\end{array}$ & $\begin{array}{c}\text { Export in } \\
\text { non-SMEA } \\
\text { countries in } \\
1990 \text { as a } \\
\text { percentage } \\
\text { of official } \\
\text { GDP }\end{array}$ & $\begin{array}{l}\text { Shadow GDP } \\
\text { in pre-reform } \\
\text { year as a } \\
\text { percentage of } \\
\text { total GDP }\end{array}$ & $\begin{array}{l}\text { Increment of } \\
\text { privatization } \\
\text { index for the } \\
\text { initial three } \\
\text { year period }\end{array}$ \\
\hline & & & & EXPORT & & \\
\hline & & & Y & & BLACK & DPR \\
\hline 1 & Azerbaijan & 92 & 53 & 2.9 & 22.7 & 0,033 \\
\hline 2 & Belarus & 92 & 79 & 5.5 & 16.6 & 0,167 \\
\hline 3 & Bulgaria & 91 & 82 & 10.7 & 25.1 & 0,167 \\
\hline & $\begin{array}{l}\text { Czech } \\
\text { Republic }\end{array}$ & 90 & 93 & 14.2 & 6.0 & 0.633 \\
\hline 5 & Estonia & 90 & 74 & 1.7 & 12.0 & 0.167 \\
\hline 6 & Georgia & 91 & 39 & 1.9 & 24.9 & 0.067 \\
\hline 7 & Hungary & 90 & 88 & 18.2 & 27.0 & 0.367 \\
\hline 8 & Kazakhstan & 91 & 70 & 2.2 & 17.0 & 0.100 \\
\hline 9 & Latvia & 90 & 64 & 1.7 & 12.0 & 0.100 \\
\hline 10 & Lithuania & 90 & 69 & 3.3 & 12.0 & 0.167 \\
\hline & $\begin{array}{l}\text { Republic of } \\
\text { Moldova }\end{array}$ & 92 & 50 & 2.0 & 27.1 & 0.200 \\
\hline 12 & Poland & 90 & 96 & 16.5 & 15.7 & 0.233 \\
\hline 13 & Romania & 90 & 82 & 8.6 & 22.3 & 0.233 \\
\hline 14 & Russia & 92 & 68 & 10.1 & 23.5 & 0.400 \\
\hline 15 & Slovakia & 90 & 87 & 14.2 & 6.0 & 0.633 \\
\hline 16 & Ukraine & 92 & 57 & 5.4 & 25.6 & 0.067 \\
\hline
\end{tabular}

Sources: Economic Survey of Europe (2001, p. 254), De Melo, Denizer, Gelb, Tenev (1997, Table 1), Jonson, Kaufman, Shleifer (1997, p. 183), De Melo, Denizer, Gelb (1995, Appendix).

The output was measured by average GDP for 9 years of reforms as a percentage of GDP in the pre-reform year.

Table 12 demonstrates that all regression coefficients are significant and have predicted signs. Surprisingly, this simple regression explains more than $85 \%$ of the output variance.

Table 12. Regression 
Dependent Variable: Y

Included observations: 16

\begin{tabular}{|c|c|c|c|c|}
\hline Variable & Coefficient & Std. Error & t-Statistic & Prob. \\
\hline $\mathrm{C}$ & 81.64 & 6.48 & 12.59 & 0.0000 \\
\hline EXPORT & 2.53 & 0.44 & 5.75 & 0.0001 \\
\hline BLACK & -1.03 & 0.28 & -3.70 & 0.0035 \\
\hline WAR & -15.65 & 5.15 & -3.04 & 0.0112 \\
\hline DPR & -32.49 & 15.47 & -2.10 & 0.0595 \\
\hline $\mathrm{R}^{2}$ & $\begin{array}{l}0.896 \\
0.950\end{array}$ & & & \\
\hline
\end{tabular}

Notation:

Dependent variable $\mathrm{Y}$ - average GDP as a share of pre-reform GDP.

Explanatory variables:

Export- Export for the pre-reform year as a percentage of official GDP;

Black - shadow GDP for the pre-reform year as a percentage of total GDP;

War - dummy variable for countries have been involved into war conflicts;

$\mathrm{DPR}$ - increment of a privatization index for three initial years of reforms.

\section{Conclusions}

In this paper we try to show that so-called shock therapy might be responsible for the failure of the Russian reforms since it did not take into account cultural legacy of the Soviet period and strong initial distortions.

It was also demonstrated that the most successful reformers followed a concept of gradual approach. The difference between two approaches is not a question of rates of liberalization, privatization, or deregulation but rather a problem of development of appropriate interim institutions.

The culture is a much more inertial system than political and economic organizations of a society or even knowledge (Almond, 1989). Prices may be liberalized in a day, a parliament can be elected in a few months. It is difficult to believe that modern civic culture, a necessary element for success of the market economy, can arise in a short time. If the culture is important for success of reforms then strengthening enforcement of modern market behavior may be inefficient or even impossible. It does not mean that the reforms have to be postponed. However, we have to think about a reform strategy as a function of cultural parameters. For every set of cultural norms, one has to learn how to design a compatible system of organizations and laws that moves the norms towards more advanced ones, so that the 
whole process approaches modern efficient institutional frameworks. This is an important task for future research.

\section{References}

Almond, Gabriel A., and Sidney Verba (1963). The Civic Culture. Political Attitudes and Democracy in Five Nations. Princeton: Princeton University Press. 562 pp.

Almond, Gabriel A. (1989). The Intellectual History of the Civic Culture Concept. In: Almond, Gabriel A., and Sidney Verba (eds.). The Civic Culture Revisited. Newbury Park. Sage Publications. 1-56.

Almond, Gabriel A., and Sidney Verba (eds.) (1989). The Civic Culture Revisited. Newbury Park. Sage Publications. 1-56.

Bruno, Michael (1993). Crisis, Stabilization and Economic Reform. Clarendon Press, 1993, 300pp.

Casson, M. (1993). Cultural Determinants of Economic Performance. Journal of Comparative Economcs, 17, 418-442.

Cazes, B. (1990). Indicative Planning in France. Journal of Comparative Economics 14 (4), 607-620.

Conradt, David P. Changing German Political Culture (1989). In: Almond, Gabriel A., and Sidney Verba (eds.). The Civic Culture Revisited. Newbury Park. Sage Publications. 212- 272.

De Melo, Martha De Melo, Martha, Cevdet Denizer, Alan Gelb (1995). From Plan to Market: Patterns of Transition. XIth World Congress of the International Economic Association. Tunis. 34 pp.

De Melo, Martha, Cevdet Denizer, Alan Gelb and Stoyan Tenev (1997)

Circumstance and choice: the role of initial conditions and policies in transition economies, The World Bank. 44 pp.

Dolgopyatova, Tatiana (1995). Rossiyskiye Predpriyatiya V Perehodnoy Ekonomike: Ekonomicheskiye Problemy i Povedeniye. Moskva: Delo Ltd. 285 pp (in Russian).

Dubin, Boris (1999). Religiosnaya vera v Rossii 90-yh godov. (Religious Faith in Russia of the 1990s). Monitoring obschestvennogo mneniya, (The Russian Public Opinion Monitor), No.1(39), Jan.-Feb.1999. 31-38 (in Russian). 
Economic Survey of Europe (2001). No. 1. Economic Commission for Europe. United Nations : N. Y. and Geneva..

Economic Survey of Europe (2002). No. 1. Statistical Appendix. Economic Commission for Europe. United Nations : N. Y. and Geneva. 216- 246.

Fang, H. ( 2001). Social Culture and Economic Performance. The American Economic Review, 91, N.4, 924-937.

Fridman, L.A. Essays on economic and social development of Central Asia countries after disintegration of the USSR. Moscow: "Gumanitarij". 211 pp. (in Russian).

Gromova, Regina (1998). A Comparative Analysis of the Typical Forms of Social Mobility in the Russian Society before and after 1985. The Russian Public Opinion Monitor, 1 (33), 18-26 (in Russian).

Gudkov, Lev (1999). Rossiya v ryadu drugih stran: k probleme nazional'noi identichnosti. (Russia amidst Other Countries: Concerning the Problem of National Identity). Monitoring obschestvennogo mneniya, (The Russian Public Opinion Monitor), No.1(39), Jan.-Feb.1999. 39-46 (in Russian).

Gaidar, Egor (1996). Dni porazhenij i pobed. M.: Vagrius. 367 pp (in Russian).

Haarland, Hans-Peter, and Hans-Ioahim Niessen .1999. Barometer of Transformation in Eastern Europe in 1999. The Russian Public Opinion Monitor, 6 (44), 13-17 (in Russian).

Hellman J.S., Jones G., Kaufmann D., and Schankerman M. (2000). Measuring Governance, Corruption, and State Capture. Policy Research Working Paper, No.2312, The World Bank Institute, April.

Hellman, J. and M.Schankerman. (2000). Intervention, Corruption and Capture. The nexus between enterprises and the state. Economics of Transition, vol.8(3), 545-576.

Hillman A.L. (1999). In Transit to the Promised Land: Ten Years in the Wilderness without Moses. Paper presented at $5^{\text {th }}$ Dubrovnik Conference on Transition Economies. 43 pp.

Hillman, A.L. and Ursprung H.W.( 2000). Political Culture and Economic Decline. European Journal of Political Economy . Vol. 16, No. 2. 190- 213.

Houben, Vincent (1999). Economic crisis and the culture of reform in Southeast Asia. European Review, v.7, No.4, 487-496. 
Information : Surveys' Findings. (1999). The Russian Public Opinion Monitor, No.1(39), Jan.-Feb.1999. 60-96 (in Russian).

Information : Surveys' Findings (2002). The Russian Public Opinion Monitor, No.4(60), 62-98 (in Russian).

Jones, Derek C. (1998). The Economic Effects of Privatization: Evidence from a Russian Panel. Comp. Econ. St. XXXX, 2: 75-102, Summer.

Johnson, Simon, Daniel Kaufmann, Andrei Shleifer (1997). The Unofficial

Economy in Transition, Brookings Papers on Economixc Activity, vol. 2, 159- 239.

Kapeljushnikov, R. I. (2001). Russian labor market. Adaptation without restructuring. Moscow: HSE. 308 pp. (in Russian).

Katyshev, P. K., and V. M. Polterovich (2002). Initial conditions, reform policy, and transformational recession. Manuscript (in Russian).

Khakhulina, Ludmila (1999). Social Inequality in Russian Society: opinions and assessments. Barometer of Transformation in Eastern Europe in 1999. The Russian Public Opinion Monitor, 4 (42), 27-30 (in Russian).

Kornai, Janos (1985a). Efficiency and the Principles of Socialist Ethics, In: Contradictions and Dilemmas. Corvina. 124-138.

Kornai, Janos (1985b). Degrees of Paternalism. In: Contradictions and Dilemmas. Corvina. 52-61.

Levada, Yuri (2000). "Homo Praevaricatus" : Russian Double-Think. The Russian Public Opinion Monitor, 1 (45), 19-26 (in Russian).

Levada, Yurij (1998). Reverting to the Problem of Social Elite. Monitoring obschestvennogo mneniya, (The Russian Public Opinion Monitor), No.1 (33), 12-18 (in Russian).

Levada, Yurij (1999). 1989-1998: Desyatiletie vynuzhdennyh povorotov. (Ten Years of Forced Turns). Monitoring obschestvennogo mneniya, (The Russian Public Opinion Monitor), No.1(39), Jan.-Feb.1999. 7-11 (in Russian).

Levada, Yurij (1999a). "Homo Soveticus" Ten Years Later: 19891999(Introductory Results of a Comparative Research). Monitoring obschestvennogo mneniya, (The Russian Public Opinion Monitor), No.3 (41), 7-15 (in Russian).

Levada, Yurij (1999b). "Homo Adapticus". Monitoring obschestvennogo mneniya, (The Russian Public Opinion Monitor), No.5 (43), 7-16 (in Russian). 
Lijphart, Arend (1989). The Structure of Inference. In: Almond, Gabriel A., and Sidney Verba (eds.). The Civic Culture Revisited. Newbury Park. Sage Publications. $37-56$.

Li, David (1998). Changing Incentives of the Chinese Bureaucracy. AEA Papers and Proceedings. Vol.88, 1998, No. 2, 393-403.

Linz, Susan J. (1998). Job Rights in Russian Firms: Endangered or Extinct

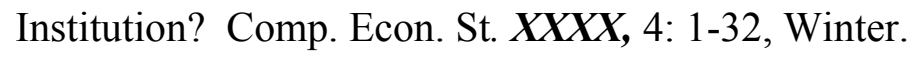

Magnus Jan, Victor Polterovich, Anatoly Danilov, Alexei Savvateev (2001). Tolerance to Cheating: A Cross Country Analysis. Journal of Economic Education (in print).

McCallum J., Blais A. (1987). Government, special interest groups, and economic growth. Public Choice, 54, 3-18.

Nikitina, Vera (2000). Monitoring obschestvennogo mneniya, (The Russian Public Opinion Monitor), No.1(45), Jan.-Feb.2000. 49-54.

North, D. (1997). Institutions, Institutional Change and Economic

Performance. New York: Cambridge University Press.

Olson Mansur Jr., Sarna N. and Swamy A.V. (1998). Governance and growth: A simple hypothesis explaining cross-country differences in productivity growth. Public Choice, 102, 341-364.

Polterovich, Victor (2000). Institutional Traps. In: Lawrence R. Klein and Marshall Pomer (eds.), The New Russia: Transition Gone Awry. Stanford, Stanford University Press. 93-116.

Polterovich, Victor (1998). Factors of Corruption. Economics and Mathematical Methods, 34, No. 3, 30-39 (in Russian).

Polterovich, Victor (1995). Economic reform in Russia in 1992: The Government

Battles Labor Collectives.” J. Inter. Comp. Econ. 4:265-287.

Rossiyskiy statisticheskiy ezhegodnik (1996). Moskva: Goskomstat (in Russian).

Sotsial'no-ekonomicheskoye polozheniye Rossiyskoy Federatsii (1996). No.12. Moskva: Goskomstat Rossiyskoy Federatsii (in Russian).

Shleifer A. (1997). Government in Transition. European Economic Review, v.41, p.385-410. 
Stiglitz, Joseph E (1997). More Instruments and Broader Goals: Moving Toward the Post-Washington Consensus. Wider Annual Lectures 2. The United Nations University, May.

Stiglitz, Joseph (1998). Distinguished Lecture on Economics in Government. The Private Uses of Public Interests: Incentives and Institutions. Journal of Economic Perspectives, v.12, No.2, 3-22.

Zak, P.J. and S.Knack. (2001). Trust and Growth. The Economic Journal, 3(April), 295-321.

Zdravomuslov, A. (2002). National Self-Awareness of Russians. The Russian Public Opinion Monitor, 2 (58), 48-53 (in Russian).

Zorkaya, Natalia (1999). Interest in Politics as a Form of Political Participation. The Russian Public Opinion Monitor, 4 (42), 12-19 (in Russian).

Zorkaya, Natalya (1999). Political Participation and the Population's Confidence in Political Institutions and Political Leaders. The Russian Public Opinion Monitor, 1(39), 24 - 27 (in Russian).

Zorkaya, Natalya (1995). Who Has Retained Interest in Politics? Economic and Social Change. The Monitoring of Public Opinion. No.2 20- 22 (in Russian).

World Development Report (1997). The State in Changing World. World Bank, Washington. 
